УДК 340.12

\title{
Russian Law-Interpretative Policy and the Eurasian Economic Union Development
}

\author{
Alexander V. Malko ${ }^{\mathrm{a}}$ \\ and Evgeniy M. Terekhov ${ }^{\mathrm{b} *}$ \\ ${ }^{a}$ Saratov Branch of Institute of State and Law \\ Russian Academy of Science \\ 135 Chernyshevsky Str., Saratov, 410028, Russia \\ ${ }^{b}$ Department of State and Law Disciplines, \\ Balakovo Branch of the Saratov State Academy of Law \\ 8/1 Red Star Str., Balakovo, 413865, Russia
}

Received 02.04.2018, received in revised form 27.05.2018, accepted 04.06.2018

The article shows the importance of introducing an interpretative form of implementing the legal policy in the context of globalization as exemplified by the Eurasian Economic Union functioning. Basing on the logical method, the authors' definition of the "interpretative form of the legal policy implementation" concept is given; application of the modeling method results in the specific steps which are proposed to improve the international interpretation; with the help of the systematic method the specifics of the interpretative acts functioning within the framework of the Eurasian Economic Union are revealed. The authors state the lack of attention, chained to the modern law-interpretative policy. The current problems are analyzed and the ways to overcome them are suggested. A focus of attention is given to the need for the legislative regulation of the mechanism of using the interpretative acts of the bodies of interstate associations in the domestic legal system. This work can be used to improve both the European Union legislation and the legislation of its member states and to overcome the emerging legal difficulties.

Keywords: legal policy, law-interpretative policy, legal activity, law-interpretative activity, law interpretation, interpretative act, interpretation practice.

DOI: 10.17516/1997-1370-0283.

Research area: law.

\section{Introduction}

Nowadays, the international community is completely obsessed with the globalization processes. Every year billion dollars transactions are concluded, contracts on cooperation in various spheres of public life are signed. The phenomenon of globalization is increasingly becoming one of the most significant factors determining the features of the human civilization development (Mazurenko, Rysina, 2012).

The dynamic development of international relations requires a more active use of the potential not only for law-making and law-enforcement activities but for a law-interpretative one as well.

(c) Siberian Federal University. All rights reserved

* Corresponding author E-mail address: i_gp@ssla.ru; terehov1989@yandex.ru 
That is why there is a need for harmonization and unification of law interpretation problems. The solution of this problem is primarily focused on the interpretative form of legal policy implementation (law interpretative policy).

The interpretative form is an independent type of legal policy. It is aimed at improving the scope of official interpretation of the law. It allows for the unified implementation of law interpretative activities; reduction of conflicting interpretative practice; creation of the conditions for a better assimilation of the law interpretation results.

\section{Diversity of views on the problem of the interpretative form of legal policy implementation}

Today the "interpretative form of legal policy implementation" is in the process of formation. Thus, there is neither a full-fledged picture nor a clearly formed opinion about its nature. That is why all the talk about this phenomenon is only in terms of staging so far.

E.A. Bogoslavskii concludes that the interpretative form of legal policy implementation is a result of the specially authorized bodies' activity on legal provisions interpretation that is necessary to ensure the legal policy effectiveness (Bogoslavskii, 2015).

O.L. Soldatkina states that the interpretative form of legal policy implementation is the specially authorized entities' activity aimed at unifying the understanding of meaning and content of the legislator's true goals and objectives, expressed in the norms of law (Soldatkina, 2010).

R.V. Puzikov believes that it implies the idea of the relevant subjects' conscious intellectualand-volitional activity aimed at understanding and explaining the legislator's true goals and objectives expressed in the norms of law and with a view to the most accurate enforcement (Puzikov, 2008). This approach does not seem entirely rational since it turns out that the interpretative form of legal policy implementation does not differ from the law interpretation which is nothing more than an intellectual-and-volitional activity to clarify and explain the meaning of legal norms for their most correct implementation.

It is hard not to agree with V.A. Rudkovskii's view that in justification of the policy under consideration it is obviously necessary to proceed from the fact that, on the one hand, law interpretation is as an integral component of law enforcement. On the other hand, it forms a relatively independent type of legal activity (Rudkovskii, 2009). It is important to note that law interpretation is just a prerequisite necessary for the effective law enforcement. Thus, consequently, the quality of the law enforcement activity depends on the level of the interpretative form of legal policy implementation development. In our opinion, the interpretative form of legal policy implementation is the state bodies' and civil society institutions' scientifically based, consistent and systemic activities aimed at determining the strategy and tactics of interpreting the legal norms, creating the necessary conditions for an effective interpretation of legal regulations.

The signs of the interpretative form of legal policy implementation are important since they are the main characteristics to distinguish it from the related categories and are a kind of elements focused on a detailed construction of mental activity.

The signs are the characteristic features of the interpretative form of the legal policy implementation within the framework of which interpretation is carried out.

The most significant signs we can distinguish are the following ones:

1) It represents a form of concretization of the overall political and legal strategy applicable to law interpretative activities. 
Political-and-legal strategy has many different directions of its action. It is obvious that the interpretative form of legal policy implementation should specify this strategy for the law interpretative activity.

2) It has specific objectives and specific means of their achievement.

We distinguish the following objectives: optimization of interpretation, formation of the environment conducive to better understanding of the meaning of legal norms, definition of the strategy and tactics of the interpretative activity of the subjects of interpretation, implementation of a qualitative and effective law enforcement policy, integration of interpretation activities, etc.

The instruments of the law interpretative policy are interpretative legal technique, interpretative practice, interpretative legal acts, information-and-interpretative resources, etc.;

3) It is characterized by its own subject composition.

The subjects of the interpretative form are the bodies of legislative, executive, and judicial power; the President of the Russian Federation; the prosecutors of Russia.

It is worth while noting that these are not only the state authorities that act as the subjects of the law interpretative policy. The world community, represented by the international organizations, also makes a significant contribution to its formation (Abramov, 2018).

4) It is embodied in the adoption of the interpretative acts.

They express the nature of the process of law interpretation since the interpretative act is a final result of the subjects' law-interpretative activity. With the help of such acts, the state can influence the public relations when determining the future line of the law enforcement activity.

As an independent form of legal policy implementation, its interpretative form is carried out at the international, federal, regional, municipal, and local levels.

At the international level, the interpretative form of legal policy implementation functions through the optimization of the interpretation of the international treaties of the Russian Federation as well as the compliance of domestic legal norms with the universally recognized principles and norms of the international law.

\section{Importance of the law-interpretative policy for globalization}

It is worth while considering the role of the interpretative form of implementing the Russian legal policy in the Eurasian integration basing on the example of the Eurasian Economic Union functioning, the Russian Federation being its full-fledged member state.

On May 29, 2014 the Agreement on the Eurasian Economic Union (Dogovor o Evraziiskom ekonomicheskom soiuze...) was signed in Astana. It was ratified by the Federal Law Art. 279-FZ of October 03, 014 (Federal'nyi zakon ot 03.10.2014...).

This fact means not only the emergence of active cooperation between the member states of the Union, but, above all, the change in their national legislation and the need to develop and operate a single legal mechanism for the Eurasian Economic Union activities.

Such integration has caused certain ambiguities in the field of establishing a single legal field, and namely the boundaries of the relationship between the law of the Union and the rights of the participating states; the limits of the Union bodies' law-interpretative activity; the ambiguity of the legal nature of the legal acts of the Union as well as the degree of impact on the national legal regulation (Mal'ko, Gaivoronskaia, 2018).

A mandatory question to be answered by the interpretative form of legal policy implementation 
in the context of globalization is to explain various legal acts within the framework of the Eurasian Economic Union for each state-member.

Article 6 of the Treaty on the Eurasian Economic Union states that its legal system is represented by the following acts: the present contract; the international treaties concluded within the framework of the Union; the international agreements of the Union concluded with the third parties; the decisions and orders of the Union's bodies (the Supreme Eurasian Economic Council, the Eurasian Intergovernmental Council, the Eurasian Economic Commission).

It is understood that the legal status of these acts has different legal force, which directly affects not only the need for their execution, but also the issue of using the appropriate interpretative acts in the Russian legal system.

The compulsory interpretation of the interpretative acts on the interpretation of the norms of the Treaty on the Eurasian Economic Union is beyond doubt, which is due to the following. According to Part 4 of Article 15 of the Constitution of the Russian Federation (Konstitutsiia Rossiiskoi Federatsii ot 12.10.1993...), international treaties are an integral part of the Russian legal system. In Paragraph 8 of the Resolution of the Plenum of the Supreme Court of the Russian Federation of October 10, 2003 No. 5 it is stated that the rules of the current international treaty of the Russian Federation have priority over the laws of the Russian Federation (Postanovlenie Plenuma Verkhovnogo Suda ot 10.10.2003...). For example, on December 11, 2017 the Court of the Eurasian Economic Union issued an advisory opinion on clarification of the provisions of Articles 9 and 99 of the Treaty on the Eurasian Economic Union of May 29, 2014, Paragraph 43 of the Regulations on Social Guarantees, Privileges and Immunities in the Eurasian
Economic Union (Konsul'tativnoe zakliuchenie Suda Evraziiskogo ekonomicheskogo soiuza ot 11.12.2017...).

Similar to the international treaties of the Eurasian Economic Union with third parties, there are some difficulties regarding the international treaties concluded within the framework of the Eurasian Economic Union.

On the one hand, in the domestic legal system they are implemented in multiple ways. In the case of ratification, they are given greater legal validity in comparison with the laws of the Russian Federation. As for non-ratified contracts, they are vested with greater legal force, if compared with the by-laws of the Russian Federation. On the other hand, the researchers rightly emphasize the need for a special regulation of the legal nature of the Eurasian Union acts in comparison with the general regulation of the status and applicability of the international treaties in the Russian Federation (Mal'ko, Gaivoronskaia, 2018). This is explained by the fact that to date the Eurasian Economic Union legal acts have different legal force in the EAEC member countries and their place in the national legal systems is also different.

Article 6 of the Treaty on the Eurasian Economic Union stipulates that the decisions of the Supreme Eurasian Economic Council as well as of the Eurasian Intergovernmental Council are subject to execution by the member states in the manner provided for by their national law. However, in modern Russian law the procedure for these bodies' legal acts implementation has not been regulated yet.

V.D. Ipatov, analyzing the problem noted, concludes that it is necessary to not only develop a mechanism for implementing the legal acts of the Supreme Eurasian Economic Council and the Eurasian Intergovernmental Council but also legislatively provide for the necessary time for this (Ipatov, 2015). 
Legal acts of the Eurasian Economic Commission are directly applied not only in the territory of the Russian Federation, but also in the territories of other member states of the Union, which is stipulated in Paragraph 13 of annex Art. 1 of the Treaty on the Eurasian Economic Union.

OnNovember21,2017, theEurasianEconomic Commission issued the recommendation to Art. 27 "On common approaches to the implementation by the Eurasian Economic Union member states of a coordinated policy in the field of consumer protection in the sale of goods (works, services) by remote means", explaining the concepts of individual entrepreneur, personal information, sale of goods (works, services) by remote means (Rekomendatsiia Evraziiskoi ekonomicheskoi komissii ot 21.11.2017...) etc. Russia is obliged to take such interpretative acts into account.

However, the place of such interpretative acts in the system of interpretative acts of Russia, the procedure for the actions in case of a collision between the EAEC bodies' other interpretative acts and the law-interpretive activities of the Russian subjects are incomprehensible. These moments, in our opinion, must be legally regulated.

Unlike in Russia, in Belarus and Kazakhstan the situation with the application of legal acts by the bodies of interstate associations has received its legislative approval.
In the territory of the Republic of Belarus, the legal acts of the Eurasian Economic Union bodies have a subordinate character, which is stipulated in the Constitution (Pimenova, 2014). This means that in case when the interpretative acts of the bodies of interstate associations contradict with the acts of the norms of the law interpretation by the state authorities of Belarus, the priority is given to the latter.

In Kazakhstan, the legal acts of the Eurasian Economic Union bodies take precedence over the acts of the Kazakhstan government bodies (Normativnoe postanovlenie Konstitutsionnogo Soveta Respubliki Kazakhstan ot 05.11.2009...). This means that in case of contradiction of the interpretative acts of the bodies of interstate associations with the acts of interpretation of the norms of law by the state authorities of Kazakhstan, the priority is given to the former.

\section{Conclusion}

Thus, it becomes more and more obvious that a full regionalization within the framework of the Eurasian Economic Union functioning is impossible without a legislative decision on the status of legal acts, including the interpretative ones. The effectiveness of the interstate association is being questioned.

\section{References}

Abramov, P.V. (2018). Effektivnost' sotsial'no-pravovoi politiki gosudarstva [Effectiveness of Social and Legal Policy of the State]. Moscow, Iuniti-Dana, $111 \mathrm{p}$.

Bogoslavskii, E.A. (2015). Kontrol' i nadzor kak forma realizatsii pravovoi politiki [Control and Supervision as a Form of the Legal Policy Implementation]. Moscow, Nauchno-issledovatel'skii institut istorii, ekonomiki i prava, $122 \mathrm{p}$.

Dogovor o Evraziiskom ekonomicheskom soiuze (podpisan v g. Astane 29.05.2014) [The Treaty on the Eurasian Economic Union (signed in Astana on May 29, 2014)]. Available at: http://www.pravo. gov.ru (accessed 16 January 2015).

Federal'nyi zakon ot 03.10.2014 № 279-FZ “O ratifikatsii Dogovora o Evraziiskom ekonomicheskom soiuze" [Federal Law No. 279-FZ of 03.10.2014 "On Ratification of the Treaty on the Eurasian Economic Union”], In Sistema konsul'tant plus [Consultant Plus System]. Available at: http://

$$
-956-
$$


www.consultant.ru/cons/cgi/online.cgi?req $=$ doc\&base $=$ LAW\&n $=169401 \&$ fld $=134 \& d s t=1000000001$, $0 \& \mathrm{rnd}=0.5745790989529431 \# 048977929848617285$ (accessed 16 March 2018).

Ipatov, V.D. (2015). Istochniki prava Evraziiskogo ekonomicheskogo soiuza ivnutrigosudarstvennyi implementatsionnyi mekhanizm [The sources of the Law of the Eurasian Economic Union and the Domestic Implementation Mechanism], In Integratsiia i pravo: opyt, sostoianie i perspektivy razvitiia [Integration and Law: Experience, State and Development Prospects], 15.05.2015. Available at: http:// www.union.by/print/event/conference2015/materials/f078d17387d85dce.html (accessed 20 February 2018).

Konstitutsiia Rossiiskoi Federatsii: priniata na vsenarodnom golosovanii 12 dekabria 1993 (s popravkami ot 30 dekabria 2008; 5 fevralia, 21 iiulia 2014) [Constitution of the Russian Federation: Adopted by the Popular Vote on December 12, 1993 (as amended on December 30, 2008, February 5, July 21, 2014)], In Sistema konsul'tant plus [Consultant Plus System]. Available at: http://www. consultant.ru/document/cons_doc_LAW_28399/(accessed 16 March 2018).

Konsul'tativnoe zakliuchenie Suda Evraziiskogo ekonomicheskogo soiuza ot 11.12.2017 № SE2-3/1-17-BK po zaiavleniiu zamestitelia direktora Departamenta tekhnicheskogo regulirovaniia i akkreditatsii Evraziiskoi ekonomicheskoi komissii Adilova Bauyrzhana Maratovicha o raziasnenii polozhenii statei 9 i 99 Dogovora o Evraziiskom ekonomicheskom soiuze ot 29 maya 2014, punkta 43 Polozheniia o sotsial'nykh garantiiakh, privilegiiakh i immunitetakh v Evraziiskom ekonomicheskom soiuze (prilozhenie № $32 \mathrm{k}$ Dogovoru o Evraziiskom ekonomicheskom soiuze ot 29 maia 2014) [The Advisory Opinion of the Court of the Eurasian Economic Union No. CE-2-3 / 1-17-BC of 11.12.2017 on the Request of Bauyrzhan Maratovich Adilov, Deputy Director of the Department for Technical Regulation and Accreditation of the Eurasian Economic Commission, on Clarifying the Provisions of Articles 9 and 99 of the Treaty on the Eurasian Economic Union of May 29, 2014, Paragraph 43 of the Regulation on Social Guarantees, Privileges and Immunities in the Eurasian Economic Union (Appendix No. 32 to the Treaty on the Eurasian Economic Union of May 29, 2014)], In Sistema konsul'tant plus [Consultant Plus System]. Available at: http://www.consultant.ru/document/cons_ doc_LAW_284899/(accessed 16 March 2018).

Mazurenko, A.P., Rysina, E.P. (2012). Optimizaciia pravotvorcheskoi politiki v usloviiakh globalizatsii [Optimization of the Lawmaking Policy in the Context of Globalization], In Rossiiskaia pravotvorcheskaia politika [Russian Lawmaking Policy], Piatigorsk: RIA-KMV, 275 p.

Mal'ko, A.V., Gaivoronskaia, Ia.V. (2018). Pravovye akty kak sredstva rossiiskoi pravovoi politiki $v$ usloviiakh globalizatsii i regionalizatsii [Legal Acts as a Means of Russian Legal Policy in the Context of Globalization and Regionalization]. Moscow, Iustitsiia, $150 \mathrm{p}$.

Normativnoe postanovlenie Konstitutsionnogo Soveta Respubliki Kazakhstan ot 05.11.2009 № 6 «Ob ofitsial'nom tolkovanii norm stat'i 4 Konstitutsii Respubliki Kazakhstan primenitel'no k poriadku ispolneniia reshenii mezhdunarodnykh organizatsii» [Normative Decision of the Constitutional Council of the Republic of Kazakhstan of 5 November 2009 No. 6 "On Official Interpretation of the Norms of Article 4 of the Constitution of the Republic of Kazakhstan in Relation to the Procedure for the Implementation of Decisions of the International Organizations"], Available at: http://www.adilet. zan.kz/rus/docs/S090000006 (accessed 20 February 2018).

Pimenova, O.I. (2014). Nadnatsional'naia pravovaia integratsiia na evraziiskom prostranstve: analiz realii i otsenka vozmozhnostei ispol'zovaniia opyta Evropeiskogo soiuza [Supranational 
Legal Integration in the Eurasian Space: Analysis of Realities and Assessment of the Possibilities of Following the European Union Experience], In Sravnitel'noe konstitutsionnoe obozrenie [Comparative Constitutional Review], 5, 21-28.

Postanovlenie Plenuma Verkhovnogo Suda RF ot 10.10.2003 № 5 "O primenenii sudami obshchei iurisdiktsii obshchepriznannykh printsipov i norm mezhdunarodnogo prava i mezhdunarodnykh dogovorov RF" [Resolution of the Plenum of the Supreme Court of the Russian Federation of 10.10.2003, No. 5 "On Application of Universally Recognized Principles and Norms of International Law and of International Treaties of the Russian Federation by Courts of General Jurisdiction"], In Sistema konsul'tant plus [Consultant Plus System]. Available at: http://www.consultant.ru/document/ cons_doc_LAW_44722/(accessed 16 March 2018).

Puzikov, R.V. (2008). Pravointerpretatsionnaia politika: sovremennoe sostoianie i tendentsii razvitiia [Law Interpretative Policy: Current State and Development Trends], In Pravovaia politika $i$ pravoviya zhizn' [Legal Policy and Legal Life], 3, 109-115.

Rekomendatsiya Evraziiskoi ekonomicheskoi komissii ot 21.11.2017 № 27 “Ob obshchikh podkhodakh $k$ provedeniiu gosudarstvami-chlenami Evraziiskogo ekonomicheskogo soiuza soglasovannoi politiki $v$ sfere zashchity prav potrebitelei pri realizatsii tovarov (rabot, uslug) distantsionnym sposobom" [Recommendation of the Eurasian Economic Commission No. 27 of November 21, 2017 "On common approaches to the implementation by the Eurasian Economic Union member states of a coordinated policy in the field of consumer protection in the sale of goods (works, services) by remote means"]. Available at: https://www.alta.ru/tamdoc/17rk0027/ (accessed 20 February 2018).

Rudkovskii, V.A. (2009). Pravovaia politika i osushchestvlenie prava [Legal Policy and Exercise of Law]. Volgograd, VA MVD Rossii, $336 \mathrm{p}$.

Soldatkina, O.L. (2010). Pravointerpretatsionnaia politika: opredelenie i sushchestvuiushchie problemy [Law Interpretative Policy: Definition and Problems], In Novaia pravovaia mysl' [New Legal Thought], 4, 6-7.

\title{
Российская правоинтерпретационная политика и развитие Евразийского экономического союза
}

\author{
А.В. Малько ${ }^{\text {a }}$, Е.М. Терехов ${ }^{\tilde{\sigma}}$ \\ а Саратовский филиал \\ Института государства и права РАН \\ Россия, 410028, Саратов, ул. Чернышевского, 135 \\ ${ }^{\sigma}$ Балаковский филиал \\ Саратовской государственной юридической академии \\ Россия, 413865, Балаково, ул. Красная Звезда, 8/1
}

В статье показана важность осуществления интерпретационной формы реализации правовой политики в контексте глобализации на примере функционирования Евразийского экономического союза. Используя логический метод, автор дает авторское определение понятия 
«интерпретаџионная форма реализации правовой политики»; на основании метода моделирования предложень конкретные шаги по усовершенствованию международного толкования; с помощью системного метода проанализирована специфика функционирования интерпретационных актов в рамках Евразийского экономического союза. Авторы отмечают недостаточность внимания к современной правоинтерпретационной политике. Анализируются имеющиеся проблемы и предлагаются пути их преодоления. Обращуается внимание на необходимость законодательной регламентации механизма использования интерпретационных актов органов межгосударственных объединений в отечественной правовой системе. Указанная работа может быть использована для совершенствования законодательства Европейского союза, его государств-участников, а также преодоления возникающчих правовых сложностей.

Ключевые слова: правовая политика, правоинтерпретационная политика, юридическая деятельность, правоинтерпретационная деятельность, толкование права, интерпретационный акт, интерпретационная практика.

Научная специальность: 12.00.00 - юридические науки. 